Alexandria Journal of Veterinary Sciences 2014, 40: 119-123

ISSN 1110-2047, www.alexjvs.com

doi: $10.5455 /$ ajvs. 149489

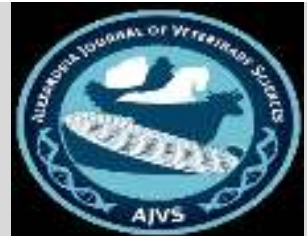

\title{
Qualitative and Quantitative Detection of Aflatoxin M1 Residues in White Soft Cheese
}

\author{
Esmat I. Awad, Ibrahim H. Amer H. Mansour and Salah-Eldeen Y. Ismail
}

Food Control Department (Milk hygiene), Faculty of Veterinary Medicine, Zagazig University, Egypt

\begin{abstract}
Key words: $\quad$ ABSTRACT:
Aflatoxin M1 in White Soft Cheese

A total of 50 random samples of locally manufactured Egyptian soft cheese including (25 each of Damietta and fresh kariesh cheese) were collected from different markets and shopkeepers at Mansoura city, Egypt. Each sample was divided under complete hygienic measures with a clean sterile, knife into two parts; the first part was prepared for estimation of by qualitative lateral flow test (strip test) and the second one was subjected to quantitative estimation of by (Immune Affinity Column with Flurometric Assay). The qualitative value for detection of Aflatoxine M1 revealed that $8(32 \%)$ and $12(48 \%)$ of kareish and Damietta cheese were contaminated with Aflatoxin M1 respectively. Concerning the concentration of Aflatoxin M1 in examined fresh Kariesh cheese and Damietta cheese samples for the minimum was 1.95 and 1.54, the maximum were 6,11 and 14.73 with a mean value 3.6 and $6.7 \mathrm{ppb}$, respectively. It had been emphasized that all results of this study exceeded the Egyptian regulations, European commission (EC) regulations and US regulations which recommend that cheese sample must be free from Aflatoxin M1, do not exceed $250 \mathrm{ng} / \mathrm{L}$, and do not exceed $5 \mu \mathrm{g} / \mathrm{kg}$ in milk, respectively. It was concluded that the qualitative method of detection of mycotoxin has great benefit in minimizing cost of regulations and monitoring and give a chance to easily set regulation for quality control. Also, quantitative methods with highly detectable limits give accurate results to estimate the level of impact.

Corresponding Author: Esmat Awad: esmatawad2@yahoo.com
\end{abstract}

\section{INTRODUCTION}

In today's changing world, safety and security have generally remained basic human needs. Ensuring the safety of food has been a major focus of international and national action over the last years. Both microbiological and chemical hazards are of concern. Among chemical hazards, the contamination of food and feed by mycotoxins as a significant sources of food-borne illnesses (WHO, 2002). Mycotoxins are toxic fungal metabolites of enormous chemical diversity that naturally contaminate the human food supply. These compounds induce an array of toxicological effects when consumed in sufficient quantities. The three major genera of mycotoxin producing fungi are Aspergillus, Fusarium, and Penicillium. The potential production of mycotoxins is insidious since fungal growth can occur both prior to and after grain harvest (Groopman and Kenssler, 2005).
The interest in mycotoxins began when aflatoxins were found to be carcinogens and to be widespread in foodstuffs and feedstuffs. Today, mycotoxins and mouldy feedstuffs are known causes of animal disease (Morgavi and Riley, 2007).

Mycotoxins induce diverse and powerful biological effects in test systems: some are carcinogenic, mutagenic, teratogenic, estrogenic, hemorrhagic, immunotoxic, nephrotoxic, hepatotoxic, dermotoxic and neurotoxic. The discovery of Aflatoxin in the early 1960s led to the resurgence of interest in human mycotoxicoses; also they are now recognized as causal factors of primary liver cancer, Ergotism and alimentary toxic aleukia (Pieter,1995).

Although mycotoxin contamination of agricultural products still occurs in the developed world, the application of modern 
agricultural practices and the presence of a legislatively regulated food processing and marketing system have greatly reduced mycotoxin exposure in these populations. However, in developing countries, where climatic and crop storage conditions are frequently conducive to fungal growth and mycotoxin production, much of the population relies on subsistence farming or on unregulated local markets. Therefore, both producers and governmental control authorities are directing their efforts toward the implementation of a correct and reliable evaluation of the real status of contamination of a lot of food commodity and, consequently, of the impact of mycotoxins on human and animal health (Dragan et al., 2010).

Chances of mycotoxin production are very small when dairy products are kept at refrigeration temperatures, Good hygiene practice is very important to fight mold spoilage. Because air is generally an effective vehicle for distribution of mold, filtration of air and even the practice of clean room techniques have been introduced in some places. Vacuum-packaging or modified atmosphere packaging is used to inhibit mold growth, and application of chemical inhibitors on wrappings and product surfaces is also used (Sørhaug, 2011). Fluid milk and dairy products should be free from aflatoxin M1 (Egyptian Regulations, 1990). According to USA regulations, the level of Aflatoxin $M 1$ in milk should not be higher than $500 \mathrm{ng} / \mathrm{kg}$. and the regulatory limits throughout the world are influenced by economic considerations and may vary from one country to another (Stoloff et al., 1991). Therefore the present study was conducted to compare between qualitative and quantitative methods for detection of Aflatoxin M1 in white soft cheese.

\section{MATERIAL and METHODS}

\subsection{Collection of samples}

A total of 50 random samples of locally manufactured Egyptian soft cheese including (25 each of Damietta and fresh kariesh cheese) were collected from different markets and shopkeepers at Mansoura city, Egypt.
Each sample was represented by about 200 250 grams of cheese which was apparently of good condition; the collected samples were transferred to the laboratory in clean, dry, sterile and tightly closed wide mouth jars, with a minimum of delay.

\subsection{Preparationofsamples}

Each sample was divided under complete hygienic measures with a clean sterile, knife into two parts; the first part was prepared for mycotoxin estimation by qualitative lateral flow test (strip test) for Aflatoxin M1 and the second one was subjected toquantitative mycotoxin estimation test by (Immuno Affinity Column with Flurometric Assay) for Aflatoxin M1.

2.3. Qualitative Aflatoxin detection by (Lateral Flow Test or Rapid Striptest):-

All samples were subjected to Lateral Flow Test (Rapid Strip Test) for Aflatoxin M1 according to (Zheng et al., 2005).

\subsection{Quantitative mycotoxin detectionby (ImmunoAffinity Column(IAC)):-}

Each sample of kariesh and Damietta cheese were undergone quantitative detection for Aflatoxin $\mathrm{M} 1$ by The Immuno Affinity Column (IAC) which had been used widely for sample clean-up in the mycotoxin analysis (Scott and Trucksess, 1997).

\section{RESULTS and DISCUSSION}

The obtained results for qualitative detection of Aflatoxin M1 table (1) revealed that $8(32 \%)$ of Kariesh cheese samples were contaminated by Aflatoxin M1 and 12 (48\%) of Damietta cheese were contaminated byAflatoxin M1.. The obtained results were in agreement with that reported by (Amra, 1998; El-Sayed et al., 2000 and Amr and Ekbal, 2010 while Abouzeid et al.,(1996) recorded lower incidences. Robinson and Tamime (1991) concluded that Aflatoxin M1 could not be detected in all manufactured cheese trials either fresh or during storage period. 
Table (1) Incidence of Aflatoxin M1 in examined soft cheese samples by Lateral Flow Test

\begin{tabular}{|c|c|c|c|}
\hline \multirow{2}{*}{ Product } & \multirow{2}{*}{$\begin{array}{l}\text { No of examined } \\
\text { Samples }\end{array}$} & \multicolumn{2}{|c|}{ Positive samples } \\
\hline & & NO & $\%$ \\
\hline Fresh kariesh cheese & 25 & 8 & 32 \\
\hline Damietta cheese & 25 & 12 & 48 \\
\hline
\end{tabular}

Table (2) Incidence and levels of Aflatoxin M1 (ppb) in examined soft cheese samples by Immuno Affinity Column

\begin{tabular}{|c|c|c|c|c|c|c|}
\hline \multirow{2}{*}{ Product } & \multirow{2}{*}{$\begin{array}{c}\text { No of } \\
\text { examined } \\
\text { Samples }\end{array}$} & \multicolumn{2}{|c|}{$\begin{array}{l}\text { Positive } \\
\text { samples }\end{array}$} & Range & & \multirow[t]{2}{*}{ Mean \pm SEM } \\
\hline & & NO & $\%$ & Min & Max & \\
\hline $\begin{array}{l}\text { Fresh kariesh } \\
\text { cheese }\end{array}$ & 25 & 8 & 32 & 1.95 & 6.11 & $3.6 \pm 0.6$ \\
\hline Damietta cheese & 25 & 12 & 48 & 1.54 & 14.73 & $6.7 \pm 1.35$ \\
\hline
\end{tabular}

Table (3): US, European Commission (EC) limits and Egyptian Standard for Aflatoxin in milk and cheese

\begin{tabular}{cccccccc}
\hline & \multicolumn{2}{c}{$(\mathrm{CS})$ standards } & \multicolumn{2}{c}{ (EC) limits } & \multicolumn{2}{c}{ Egyptian standards } \\
\cline { 2 - 8 } & Milk & Cheese & Milk & Cheese & Milk & Cheese \\
\hline Aflatoxin M1 & $0.5 \mu \mathrm{g} / \mathrm{kg}$ & Nil & $50 \mathrm{ng} / \mathrm{L}$ & $250 \mathrm{ng} / \mathrm{L}$ & Free & Free \\
\hline
\end{tabular}

Concerning the concentration of Aflatoxin M1 in examined fresh Kariesh cheese and Damietta cheese samples for the minimum was 1.95 and 1.54 , the maximum were 6,11 and 14.73 with a mean value of 3.6 and 6.7 ppb, respectively. Nearly similar finding was reported by Godic and Vengust (2008). Eman and Salem (2008) found out that the range of aflatoxin $\mathrm{M} 1$ in Kareish cheese samples was 5 to 35 (ppb) with mean value $17.5 \pm 6.61(\mathrm{ppb})$, while ElSherief (2000) examined soft cheese samples and found that the mean value was $2.61 \mu \mathrm{g} / \mathrm{kg}$. The results were higher than obtained by Assem et al. (2012) who found out that the range of aflatoxin M1 in processed cheese samples were 225 to $315 \mathrm{ng} / \mathrm{kg}$. 
Referring to Table (3) it had been emphasized that all results of this study exceeded the Egyptian Regulations, European Commission (EC) Regulations and US Regulations which recommend that cheese sample must be free from aflatoxin $\mathrm{M} 1$, do not exceed $250 \mathrm{ng} / \mathrm{L}$, and do not exceed $5 \mu \mathrm{g} / \mathrm{kg}$ in milk, respectively. Similar results were reported by Godic and Vengust (2008), Eman and Salem (2008) and El-Sayed et al. (2000) while nearly similar results were obtained by Amer and Ekbal (2010).

These results more likely to be occur in parts of the world where poor methods of food handling and storage are used and where few regulations exist to protect exposed population. Also, these results are matched with Prandini et al. (2007) who associated the high presence of Aflatoxin M1 with casein. He expressed that as an enrichment factor (EF) high curd cheese have higher Aflatoxin M1 levels than lower one. Van Egmond (1997) concluded that the most important mycotoxin occasionally found in milk and cheese products are Aflatoxin M1 and sterigmatocystin. Aflatoxin $\mathrm{M} 1$ is the result of biotransformation of Aflatoxin B1 in cows, and sterigmatocystin is produced by Aspergillus versicolor, Aspergillus nidulans and others. Aflatoxins sometimes appeared in milk, cheese and other dairy products. Growth of a toxogenic Aspergillus on a dairy product may result in contamination of that product with one or more of Aflatoxin. It is possible for cheese to contain Aflatoxin $M 1$, if made from contaminated milk, and Aflatoxin B1 and other forms of Aflatoxin if that same cheese subsequently supports growth of toxogenic Aspergilli. (Van Egmond and Dragacci, 2001). Berthiller et al., (2010) mentioned that the dairy products such as cheese are the only product really susceptible to fungal growth and production of mycotoxin. Commonly isolated fungi from cheese include Penicillium, Aspergillus, Cladosporium, Geotrichum, Mucor and Trichoderma.
Incidence of moulds in cheese and fermented dairy products indicates that those most commonly found (predominant flora) belong to the genus Penicillium. Growth of these genera in or on cheese leads to undesirable changes affecting the quality of products.

These findings reveal the presence of food borne Aflatoxin in the examined soft cheese. This will pay the attention to the problems of these toxins in food. Consequently, more restriction and preventive measures should be taken in milk herds, milk production and dairy factories in respect to quality control, sanitation and health care. The obtained Aflatoxin M1 prevalence revealed that mycotoxin has different routes to gain access to milk and milk products even in different scale of production .Also, different ways of milk product treatment or type do not affect their presence. The qualitative method of detection of mycotoxin has great benefit in minimizing cost of regulations and monitoring and give a chance to easily set regulation for quality control .Also, quantitative methods with highly detectable limits give accurate results to estimate the level of impact.

\section{REFERENCES}

Abou-zeid, A. M. Hassan, A. A. Ragheb, R. R. 1996. Mycological studies on hard (Roume) and skim milk soft cheese (Kariesh) with quantitative evaluation of the existing mycotoxin. Vet. Med. J., Giza. 44(2): 113121.

Amer, A. A. Ekbal, I. 2010. Determination of Aflatoxin $\mathrm{M} 1$ in raw milk and traditional cheeses retailed in Egyptian markets. J.Toxicol. Environ. Health Sci., 2 (4): 50-53.

Amra, H.A. 1998. Survey of Aflatoxin M1 in Egyptian raw milk by enzyme-linked Immuno Sorbent Assay. Revue de Méd. Vét. 149: 695-700.

Assem, E. El Atat, O. Habib, J. Abbas, M. 2012. Occurrence of Aflatoxin M1 in cheese processed and marketed in Lebanon.; Food Control, 25(1): 140-143. 
Berthiller, D. F. Krska, J. Lombaert, R. Malone, G. A. Maragos, B. Sabino, C. Shephard, M. Solfrizzo, G. S. Trucksess, M. M.W. 2010. Developments in mycotoxin analysis: an update for 2008-2009. World Mycotoxin J. 3: $11-16$

Dragan, R. M. Marija, Š. Tatjana, B. 2010. Real and Perceived Risks for Mycotoxin Contamination in Foods and Feeds: Challenges for Food Safety Control Institute of Meat Hygiene and Technology, Kaćanskog 13: 1100011005.

Belgrade, Serbia. Faculty of Technology, Bulevar Cara Lazara 1, 21000 Novi Sad, Serbia.

Egyptian Regulations 1990. Maximum Limits for Mycotoxin in Foods. Part L Aflatoxins E.S. 1875-1990. Egyptian Organization for Standardization and Quality Control.

El-Sayed, A. M. A. A. Neamat Allah, A. A. Soher, E. A. 2000. Situation of mycotoxins in milk, dairy Products and human milk in Egypt. Mycotoxin Research 16, 91-100.

El-Sherief, L. M. 2000. Incidence of mycoflora and some mycotoxins in locally manufactured cheese. M.V.Sc. Thesis, Fac. Vet. Med., Assuit Univ.

Eman, M. El-Diasty. Salem, R. M. 2008. Incidence of lipolytic and proteolytic fungi in some milk products and their public health significance .Faculty of Veterinary Medicine, Omar El-Mokhtar University- Libya.

Godic, K. T. Vengust, A. 2008. The presence of yeasts, moulds and Aflatoxin M1 in raw milk and cheese in Sloremia. Food Control (19) 6: 570-577.

Groopman, D. J. Kenssler, W. T. 2005. Role of metabolism and viruses in Aflatoxin-induced liver cancer, Department of Environmental Health science, The Johns Hopkines University, Bloomberg School of public health, 615 North Wolfe Street, Baltimore, MD21205, USA.

Morgavi, D. P. Riley, R. T. 2007. An historical overview of field disease outbreaks known or suspected to be caused by consumption of feeds contaminated with Fusarium toxins. Anim. Feed Sci. Technol. 137 (3-4): 201212.
Pieter, S. S. 1995. Mycotoxins, general view, chemistry and structure; SASOL Centre for Chemistry, Potchefstroom University, Potchefstroom. Republic of South Africa, Toxicol. Letters 82/83:843-851.

Prandini, A. Tansini, G. Sigolo, S. Filippi, L. Laporta, M. Piva, G. 2007. On the occurrence of Aflatoxin M1 in milk and dairy products Institute of Food Science and Nutrition, Catholic University of Piacenza, Agricultural Faculty, 29100 Piacenza, Via Emilia Parmense 84, Italy.

Robinson, P. A. Tamime. 1991. Manufacture of Feta cheese industrial. In: Feta and related cheese. 1st Ed. Ellis, H. ed Limited International Group, Academic Press, p: 70136.

Scott, P. M. Trucksess, M. W. 1997. Application of Immuno Affinity columns to mycotoxin analysis. J AOAC Int. 80:941-949.

Sørhaug, T. 2011. Spoilage Molds in Dairy Products Encyclopedia of Dairy Sciences

(Second Edition), Pages 780-784.

Stoloff, L. Van Egmond, H. P. Park, D. L. 1991. Rationales for establishment of limits and regulations for mycotoxins. Food Additives Contaminants, (Abstract).8: 213-222.

Van Egmond, H. P. 1997. Aflatoxins in milk. In: Eaton, D.L. \& Groopman, J.D., eds, The Toxicology of Aflatoxin: Human Health, Veterinary, and Agricultural Significance, San Diego, CA, Academic Press, pp. 365381.

Van Egmond, H. P. Dragacci, S. 2001. Liquid Chromatography Method for

Aflatoxin $M 1$ in Milk In method of molecularbio. Vol. mycotoxin USA.157: 5969.

WHO, 2002. Global Strategy for Food Safety: safer food for better health. Food Safety Programme. World Health Organization (WHO), Geneva, Switzerland

Zheng, M. Z. Richard, J. L. Binder, J. 2005. A review of rapid methods for the analysis of mycotoxins ,11Romer Labs Singapore Pte Ltd, 3791 Jalan Bukit Merah \#08-08, building, 159471,Singapore; Romer Labs, Inc., 1301 Stylemaster Dr., MO, 63084, Mycopathologia $\quad 161$ 261-273. 